\title{
EXPERIMENTAL EXAMINATION OF EFFECTS OF PUNCH ANGLE AND CLEARANCE ON SHEARING FORCE AND ESTIMATION OF SHEARING FORCE USING FUZZY LOGIC
}

\begin{abstract}
Summary
A significant challenge faced when using blanking/piercing to machine sheet metal is the handling of the shearing force required for high strength and thick stock. Increased shearing forces lead to the requirement of higher performance expected from the pressing machine and result in increased wear on the punch tool and die. Clearance, employed to increase precision and quality in blanking/piercing operations, affects the shearing force as well. One of the techniques used to reduce the force required is the employment of a punch shear angle. In this study, the effects of punch shear angle and clearance on the forces required for blanking/piercing were examined on a grade of steel broadly used in the manufacturing industry, DC01. Experiments were carried out using five different punch shear angles, namely $0^{\circ}, 2^{\circ}, 4^{\circ}, 8^{\circ}$, and $16^{\circ}$. Six matrices with varying clearance rates $(0.4 \% \mathrm{t}$, $0.5 \% \mathrm{t}, 0.6 \% \mathrm{t}, 0.7 \% \mathrm{t}, 0.8 \% \mathrm{t}$, and $0.9 \% \mathrm{t}$ ) were used in this study, and these clearances were altered by modular matrices on the die. This study shows that shearing forces can be reduced by $80 \%$ when $16^{\circ}$ punch angle is used. The results of the experiments were transferred to a fuzzy logic model to obtain extrapolated results for intermediate values which had not been obtained from the experiments. The results obtained from the experiments and the output from the fuzzy logic model were compared and found to be highly similar. These results have showed that the model developed using fuzzy logic can be used to determine different shear angles and clearance values.
\end{abstract}

Key words: $\quad$ punch angle, blanking, piercing, shear force, clearance, fuzzy logic

\section{Introduction}

Forming sheet metal using blanking and piercing dies is used on a large scale in the manufacturing industry. Mechanical properties of the sheet metal influence the conditions in which the blanking and piercing dies are processed. Higher strength sheet metal is getting widely used to enable the manufacturing of durable and quality products $[1,2]$. However, the use of high strength sheet metal negatively affects the mechanical processing involved. Investigations have been going on to advance the state-of-the-art technology for machining required for such metals. 
One of the commonly used methods to reduce shearing force is to make changes on the punch and die geometry. In a study, reduction in required punching force and increase in quality were observed with the use of wave-formed tools [3]. In their experimental study, Mackensen et al. [4] investigated how the punch angle used on the die affected blanking/piercing force. They used a test set-up that enabled the measurement of the orthogonal forces in effect during blanking/piercing. Their experimental results indicate that increased angles of the punch and die result in decreased blanking/piercing force and that the effect of the punch angle on the blanking/punching force is more than that of the die angle.

Studies in the last decades have indicated that clearance and punch angle are the most important factors influencing shearing force and quality of parts. These studies show that the punch angle significantly reduces the required blanking/punching force. Besides, clearance negatively affects blanking/piercing force. In addition, increased clearance values reduce the quality of the product [5,6]. Choi et al. [7] studied the effects of the clearance and the inclined angle of the die on the sheared edge characteristics of the trimmed DP980. They found that the maximum trimming load decreased with an increase in clearance due to a large bending moment, leading to a hydrostatic tensile stress in the sheared zone, and that tensile typed burr occurred at a trimming clearance above $15.6 \% \mathrm{t}$. In addition, a negative inclined angle improves the edge quality and decreases the trimming load. Lo et al. analyzed effects of shearing parameters such as punch angle, clearance, number of shearing strokes, and materials of the punch on the cutting edge [8]. Hambli et al. [9] studied the effects of clearance, tool wear, and sheet metal thickness on the blanking force. Lin et al. [10] used a neural network system to determine the relationship between clearances and punch life. Gram and Wagoner [11] examined the relationship between sheet metal being processed and blanking/piercing force. They found that hardening the punch and the die increased tool life when high strength sheet metal was being processed. Le et al. [12] investigated the effects of cutting clearance on longitudinal, transverse and diagonal orientations of the trim line relative to the rolling direction on a broadly used aluminum alloy, 6111-T4. They found that for all the sheet orientations, an increase in the cutting clearance resulted in a substantial reduction in material stretchability along the sheared surface. As a result of their analysis of the effect of the cutting angle on stretchability, they observed higher elongations with cutting angles of $10^{\circ}$ and $20^{\circ}$ for broadly used $10 \%$ clearance, compared to orthogonal cutting with an identical clearance.

Shapes and positions of the die and punch are very important to improve mechanical properties of the sheet metal parts, surface quality, and dimensional accuracy. Quazi and Shaikh [13] examined the effects of the parameters on the blanking/piercing process. They described an optimization method including experimental design, FEM analysis, and simulations. Armunanto et al. [14] explored the relationship between clearance, punch and dies circularity and circularity of the product of the punching process. In addition, distribution of clearance in a die that is used to produce sheet metal products is very important in terms of product quality. Ragu experimentally examined the effect of uneven distribution of die clearance on the quality of shear. In his study, experiments were conducted to determine the width of the "minimum die clearance zone." An adequate selection of the width ensures that there exists an optimum range of die clearance all around the punches. The quantity and severity of micro-cracks developed in the vicinity of pierced holes with the distribution of die clearance were investigated in [15]. Jaafar et al. [16, 17] developed a model to provide the eccentricity in the cutting of ultra-high strength steel sheets. In their model, a moving die provided the eccentricity between die and punch. With such a system, the distance of the burnished surface increased on the sheared edge. Through automatic centering, the position of the moving die is corrected by an imbalanced force during punching. It was found that small clearance punching with automatic centering was effective not only in improving the surface quality but also in reducing the tool failure. 
of Shearing Force Using Fuzzy Logic

It is very important to define shears, force measurements, and position of the punch in the blanking/piercing operations. Gustafsson et al. [18, 19] designed, built and verified a dedicated laboratory set-up to measure accuracy of the force and geometry. They determined that the force changed up to a level of $1 \%$.

Another widely used method in the processing of high strength sheet metal is to use warm and hot punching in order to reduce blanking/piercing resistance [20, 21]. To improve the processing conditions of high strength sheet metal, some studies used local heating of the shearing zone for reducing blanking/piercing resistance [22, 23]. The results revealed that the required blanking/piercing force was reduced and quality was improved. This method requires a heater to be attached to the die, which in turn increases costs.

In recent years, many numerical studies have been performed to determine process parameters such as clearance, tools geometry, blanking/piercing velocity, and friction on shearing force and part profile. Husson et al. [24] studied FEM simulations of the blanking process. They used a new viscoplastic model to identify flow stress on the blanking/piercing operations. Subramonian et al. [25] tried to clarify the correlation between punch, stripper plate and sheet material at different velocity rates up to $1600 \mathrm{~mm} / \mathrm{s}$. Further, they studied the effects of the different velocities on shearing force and presented a numerical model. Mitsomwang and Nagasawa investigated the unstable shearing characteristics of a polycarbonate worksheet. Mechanical conditions (such as tool clearance and feed velocity) of the shearing process were investigated in [26]. Achouri et al. [27] looked into the physical damage mechanisms that occur during the punching operation and established relevant numerical models to predict the fracture location.

The present study was performed to determine optimal clearance and punch angle values for the DC01 sheet material of $1 \mathrm{~mm}$ in thickness. In this study, a fuzzy logic system was used for the first time to make estimates of the parameter values of the shearing forces. Accordingly, the aim was to reduce the amount of energy required and scrap rates, as well as to increase tool life and product quality. Consequently, the effects of various punch angles $\left(0^{\circ}, 2^{\circ}, 4^{\circ}, 8^{\circ}\right.$, and $\left.16^{\circ}\right)$ and clearance values $(0.4 \% \mathrm{t}, 0.5 \% \mathrm{t}, 0.6 \% \mathrm{t}, 0.7 \% \mathrm{t}, 0.8 \% \mathrm{t}$, and $0.9 \% \mathrm{t})$ on blanking/piercing forces have been examined in the study. A model has been developed based on the interpretation of the die parameters and using fuzzy logic. The model output has been compared to the output obtained from the experiments conducted in this study.

\section{Materials and Methods}

DC01 brand sheet metal of $1 \mathrm{~mm}$ in thickness, which is widely employed in the manufacturing industry, was used in the experiments. Its mechanical and chemical properties relevenat for the experiments are given in Table 1.

Table 1 Mechanical and chemical properties of sheet metal used in experiments.

\begin{tabular}{ccccccc}
\hline Material & $\begin{array}{c}\text { Yield Strength }\left(\boldsymbol{\sigma}_{\mathbf{a}}\right) \\
\mathbf{N} / \mathbf{m m}^{\mathbf{2}}\end{array}$ & $\mathbf{C}$ & $\mathbf{P}$ & $\mathbf{C u}$ & $\mathbf{S}$ & $\mathbf{M n}$ \\
\hline DIN EN 10130-DC01 & 286 & 012 & 0.045 & 0.25 & 0.45 & 0.60 \\
\hline
\end{tabular}

A hydraulic press with a vertical speed control was used for the blanking/piercing tests. A modular die which holds 6 different clearances was manufactured in order to conduct the experiments. A load cell was attached to the die to measure the blanking/piercing forces in effect during the experiments. The capacity of the load cell is $240 \mathrm{kN}$. The data reading speed was adjusted to $2000 \mathrm{data} / \mathrm{sec}$ for the blanking operations. Measurements of the blanking force were carried out using this load cell. In addition, the experimental results were transferred into the digital medium by the load cell, data card, amplifier, and data display software. The signals generated by the load cell were strengthened by using an amplifier to increase the precision of 
the measurements obtained. The amplified signals were relayed to a computer using an analogto-digital converter. The test set-up was calibrated before testing, and the shearing forces corresponding to the changes in the voltages generated by the load cell were determined. The test set-up, including the die set and the load cell, are presented in Fig. 1.

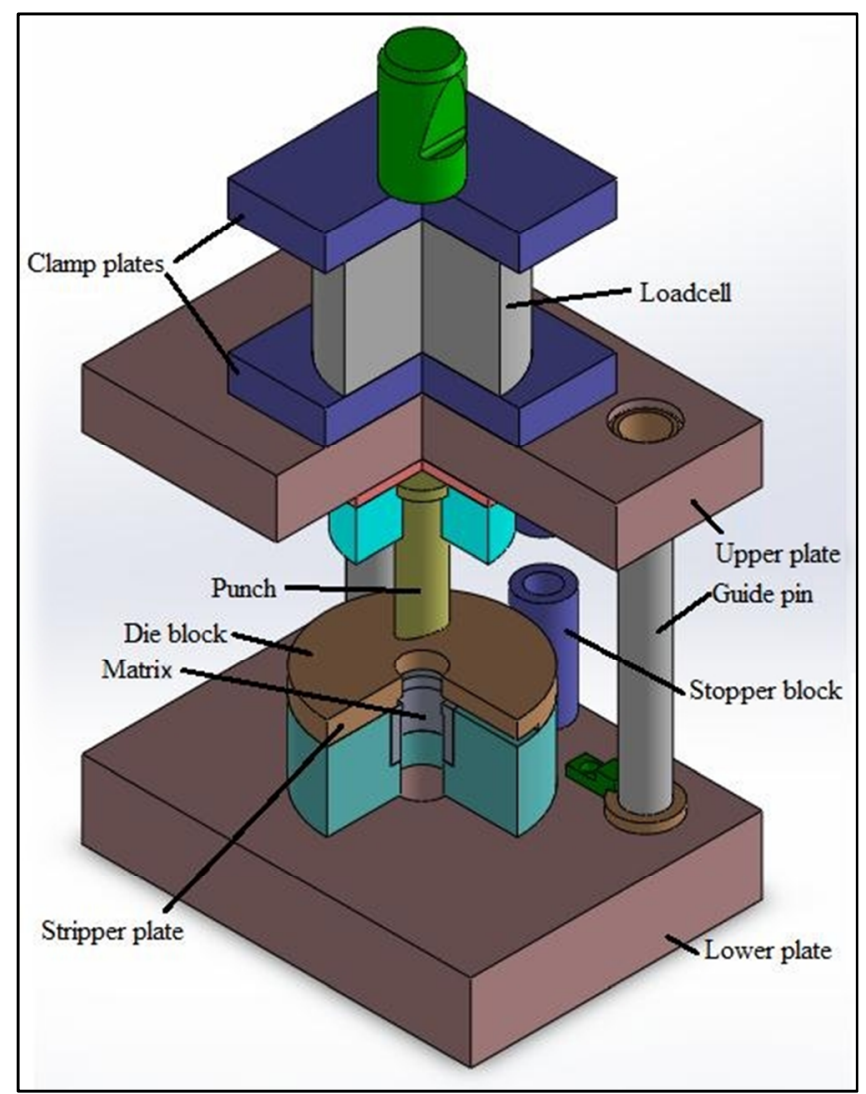

Fig. 1 Assembly of die and load cell.

Punches with a diameter of $20 \mathrm{~mm}$ were prepared using wire EDM, and the angles were precisely cut for use in the experiments. Five separate punches of angles $0^{\circ}, 2^{\circ}, 4^{\circ}, 8^{\circ}$ and $16^{\circ}$ were used in the experiments (Fig. 2). The punch clearance was set on the die. Six separate matrices were used on the die to allow changes to be made for punch clearance. The clearances in the matrices were determined as $0.4 \% \mathrm{t}, 0.5 \% \mathrm{t}, 0.6 \% \mathrm{t}, 0.7 \% \mathrm{t}, 0.8 \% \mathrm{t}$ and $0.9 \% \mathrm{t}$. 120 blanking operations were carried out, repeating each test four times to reduce the margin of error.

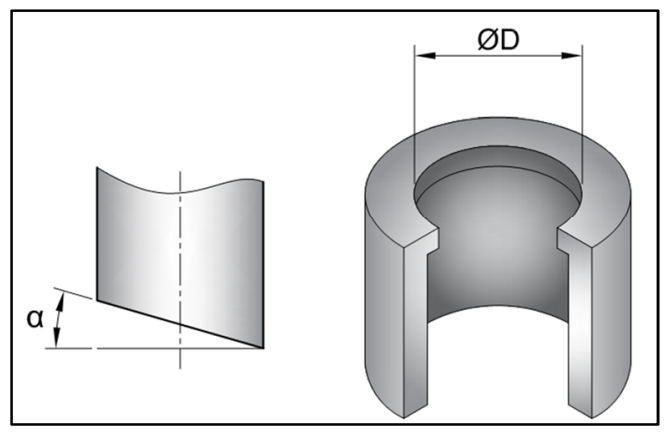

Fig. 2 Punch angle $\alpha=0^{\circ}, 2^{\circ}, 4^{\circ}, 6^{\circ}, 8^{\circ}$ and $16^{\circ}$; Clearance $=0.4 \% \mathrm{t}, 0.5 \% \mathrm{t}, 0.6 \% \mathrm{t}, 0.7 \% \mathrm{t}, 0.8 \% \mathrm{t}$ and $0.9 \% \mathrm{t}$.

A fuzzy logic system was designed by constructing a rinsing unit and a fuzzy logic rule table between input variables and output variables. The system was built according to the fuzzy logic rules which operate between input and output variables. The schematic of the fuzzy logic 
of Shearing Force Using Fuzzy Logic

system is shown in Fig. 3. In the system, punch clearance and angle are used as independent input variables, with the output variable providing the shearing (blanking/piercing) force. There is one rule block consisting of 50 rules and 15 membership functions. Some of the results obtained from the experiments were excluded from the fuzzy logic system and were instead used to test the model itself. The fuzzification unit converts numerical values in the input unit into fuzzy variables. The fuzzy inference process was set into the rule table including linguistic control rules. The outcomes of this rule table are linguistic variables. On the other hand, the defuzzification unit in the output unit reconverts these available linguistic variables into numerical values. In this study, the triangular membership functions were used during the transmission of the experimental results to the fuzzy logic system. In the fuzzy logic system, the "Compute MBF" method was used as the fuzzification method, and the "Center of Maximum (CoM)" method was used as the defuzzification method. The fuzzy logic estimations obtained were compared with the experimental data.

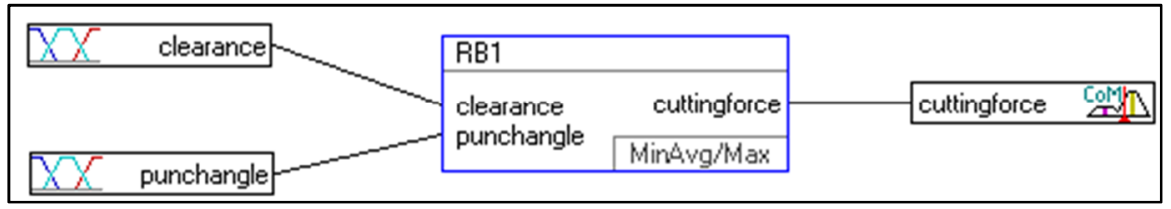

Fig. 3 Structure of the fuzzy logic system.

\section{Results and Discussion}

The results of the experiments conducted using five different punch angles and six clearance settings have shown that the shearing force is significantly affected. Fig. 4 graphically illustrates the shearing forces observed during the experiments. As the punch angle is increased, the required shearing force is significantly reduced. This study has established that shearing forces are reduced by up to $80 \%$ when different punch angles are used.

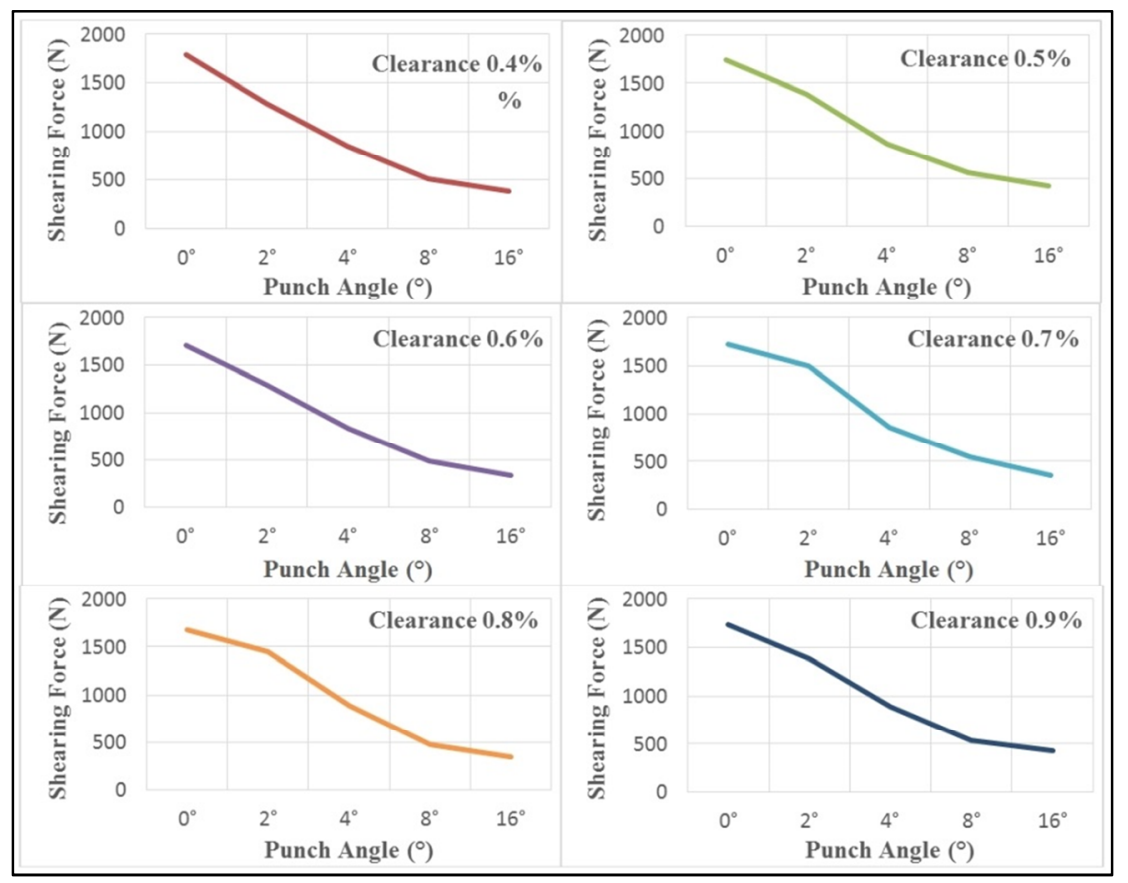

Fig. 4 Relationship of shearing forces to punch angle and clearance.

It was found that the clearance values used did not have a significant effect on the shearing force (Fig. 5). 

of Shearing Force Using Fuzzy Logic

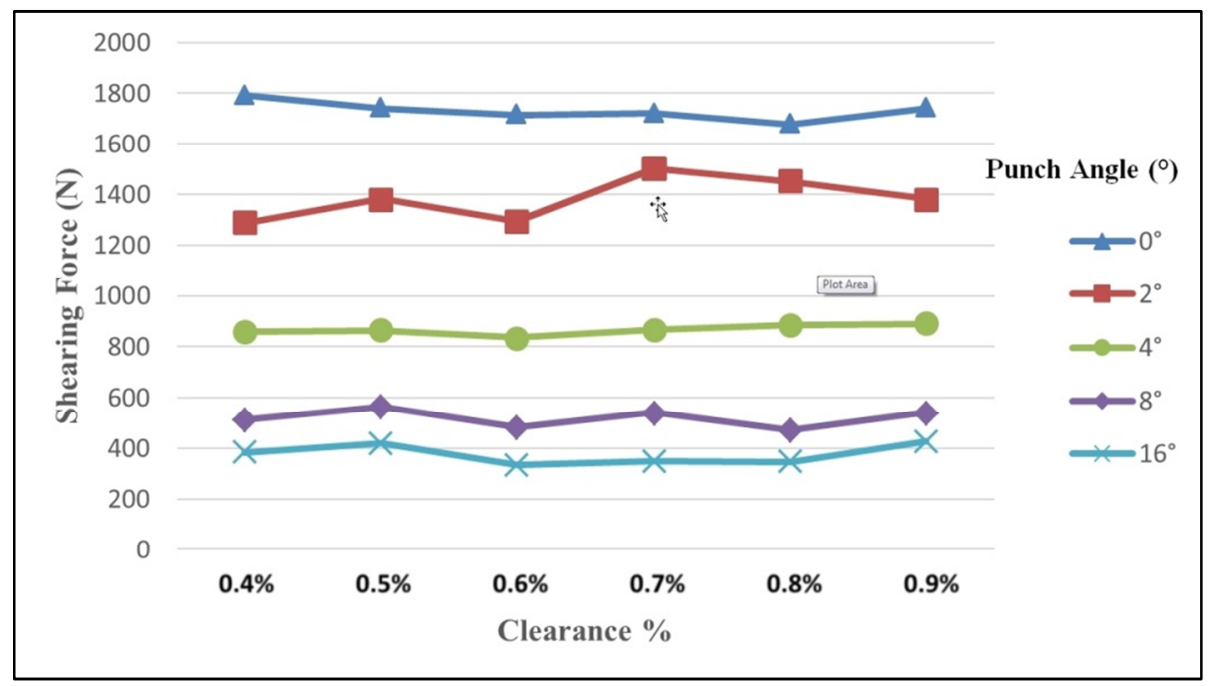

Fig. 5 Change in shearing force vs. clearance.

Blanking/piercing operations using a punch with no angle occur simultaneously in one shot along the shearing line, while the process is non-instantaneous when the punch is angled and takes a certain amount of time. The amount of penetration depth required to pierce the sheet metal increases with the punch angle used. The shearing force vs. punch motion in the case of the blanking/piercing operation performed using a clearance of $0.6 \% \mathrm{t}$ is shown in Fig. 6. While the punch angle is increased, the duration of the blanking/piercing operation is longer, and the penetration depth required to punch out the metal segment is increased. As the punch angle is increased, the maximum required shearing force is reduced.

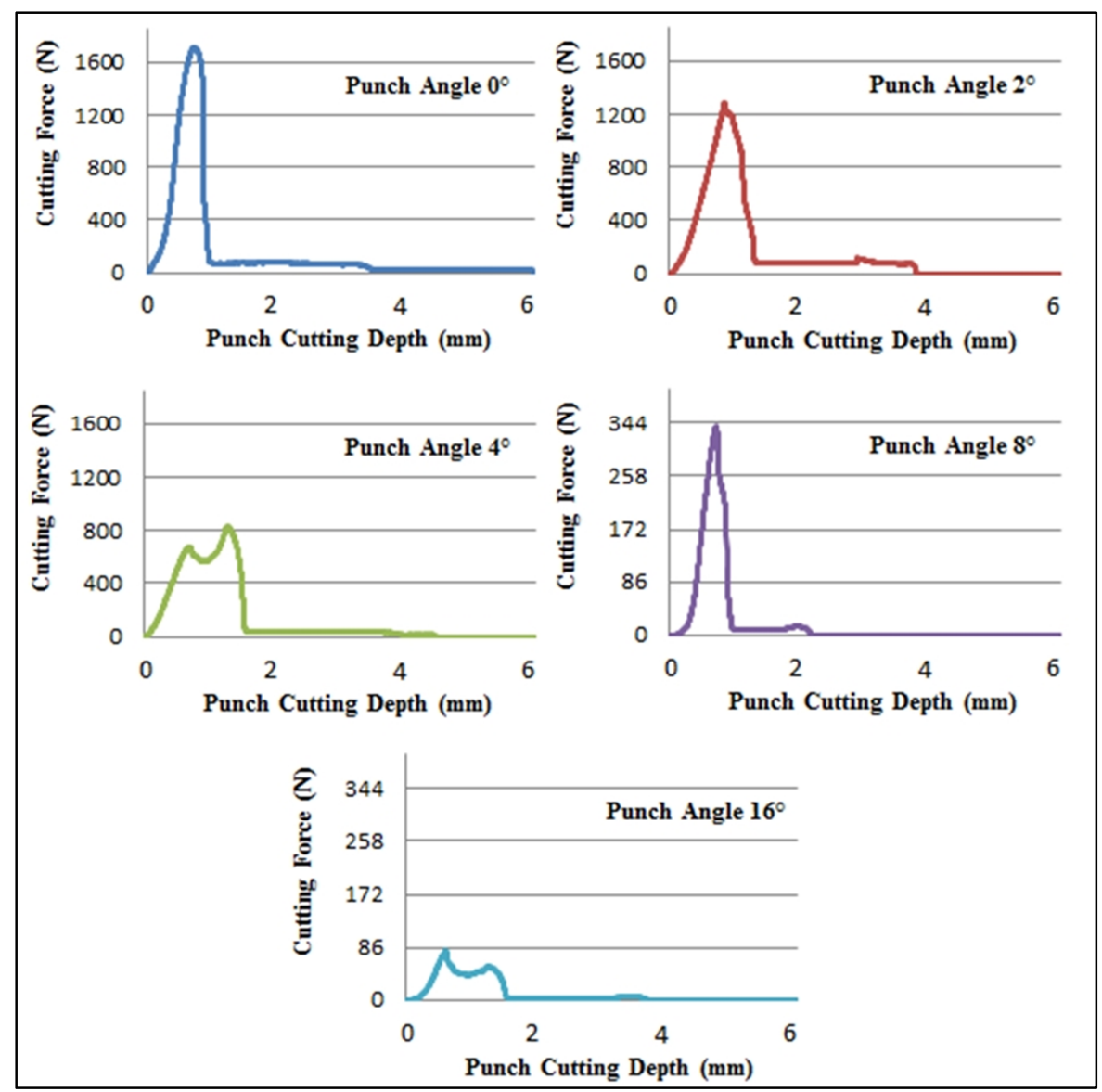

Fig. 6 Punch penetration depth vs shearing force (displayed in separate graphs). 

of Shearing Force Using Fuzzy Logic

Fig. 6 also shows that the force increases during the initial penetration of the punch, followed by a decrease, after which it levels out. The shearing force again increases as the segment is severed from the stock, after which the blanking/piercing operation is completed. Due to the angle employed, a sudden increase in the shearing force is avoided, and the impact that the punch would be subjected to is reduced; besides, the pulsing experienced during the blanking/piercing process is curtailed. The shearing force is not reduced by the same ratio for all punch angles used. The shearing force is effectively reduced up to an angle of $4^{\circ}$, after which the reduction tapers off.

An examination of the cut parts revealed that there were deformation zones on the parts due to the angle used. Fig. 7 shows the deformation of the punched out sheet metal segment. As the angled punch sheared the sheet metal, it forced the material into deformation. Consequently, deformation on the specimen in the first and second deformation sections/zones occurred, as shown in Fig. 7; the deformations are relative to the angle of the punch.

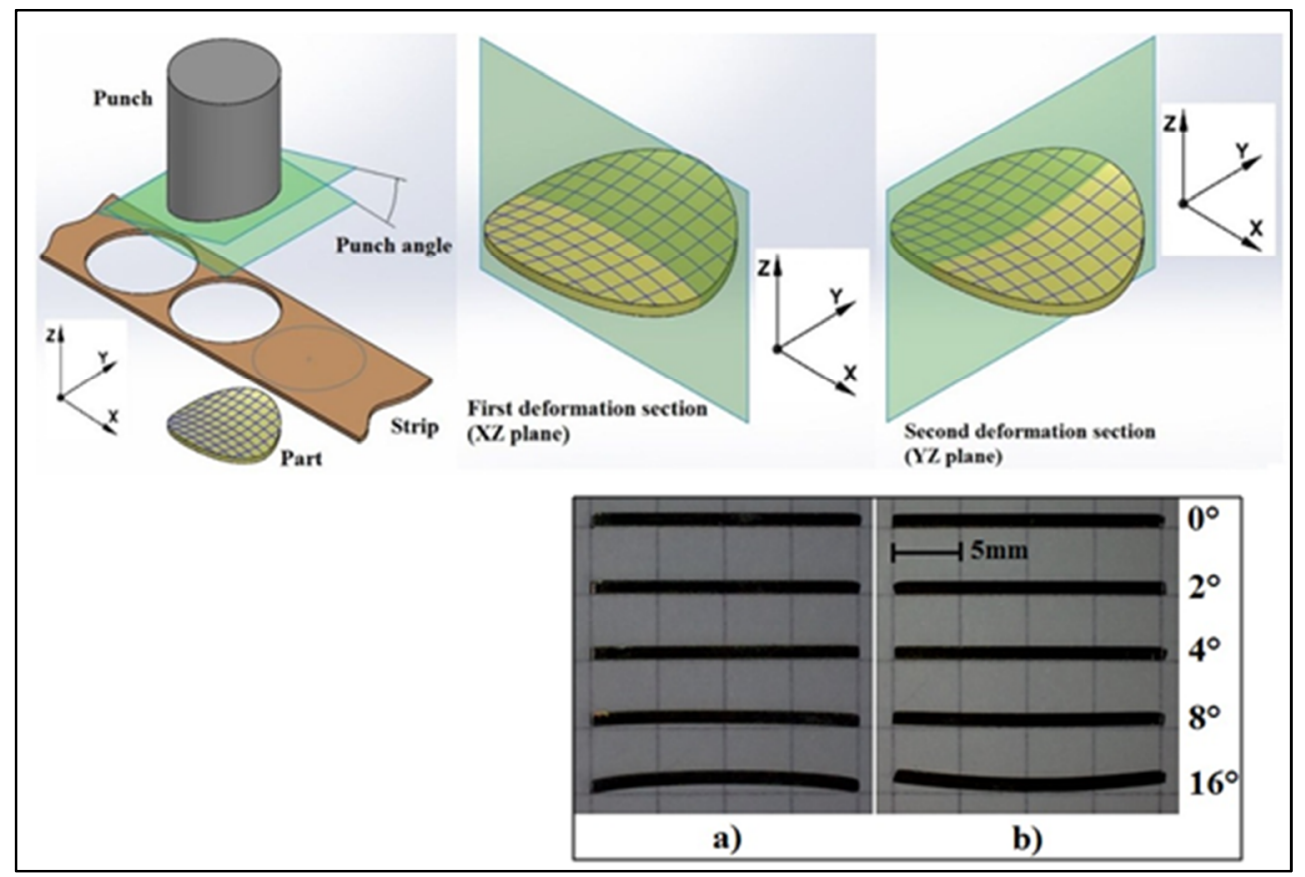

Fig. 7 Deformation zones on sheared sheet parts:

a) first deformation zone, b) second deformation zone.

The segments punched out using the angled punch were sliced by the wire EDM equipment parallel to the $\mathrm{X}-\mathrm{Z}$ and $\mathrm{Y}-\mathrm{Z}$ planes, shown in Fig. 7, to examine the amount of the present deformation. Fig. 7 also shows the amount of deformation of the specimen crosssections for each deformation plane. Accordingly, as the punch angle was increased, the amount of deformation along the first and second deformation zones increased. The directions of the first and second deformations were observed to be at a 90 degree angle.

Fig. 8 shows graphs presenting the test results and the fuzzy logic model where the shearing force vs. punch angle relationship is illustrated for the punch angle values of $0.7 \% \mathrm{t}$ and $0.9 \%$ t. The output of the fuzzy logic model and the test results are very similar to each other. The maximum deviation $\left(\mathrm{R}^{2}\right)$ values for the two distributions were calculated as 0.9788 for $0.7 \% \mathrm{t}$ and 0.9910 for $0.9 \% \mathrm{t}$. 

of Shearing Force Using Fuzzy Logic
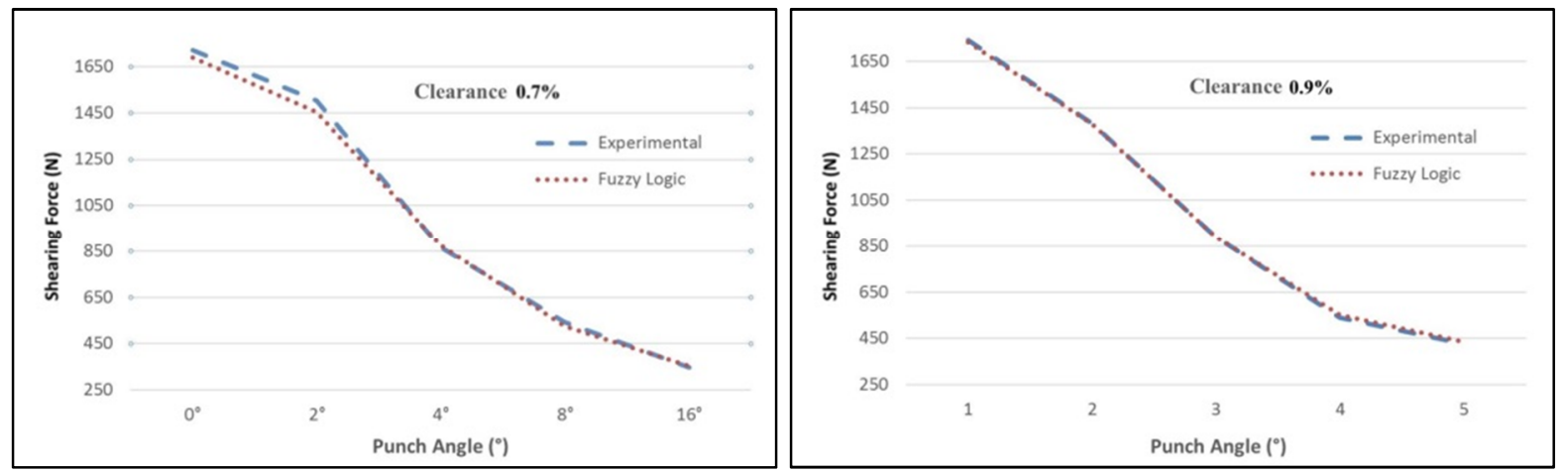

Fig. 8 Experimental results and fuzzy logic model output for clearances of $0.7 \% \mathrm{t}$ and $0.9 \% \mathrm{t}$.

\section{Conclusions}

In this study, the effects of various punch angles used to reduce the required shearing force on the blanking/piercing process were examined in experiments as well as by using a fuzzy logic model developed by the present researchers. The effects of punch clearance on shearing force were observed as well. The punches used in the testing were machined using wire EDM for angles of $0^{\circ}, 2^{\circ}, 4^{\circ}, 8^{\circ}$ and $16^{\circ}$. Six different matrices were used with clearance rates of $0.4 \% \mathrm{t}, 0.5 \% \mathrm{t}, 0.6 \% \mathrm{t}, 0.7 \% \mathrm{t}, 0.8 \% \mathrm{t}$ and $0.9 \% \mathrm{t}$. The test results indicate that shearing forces can be reduced by $80 \%$ when a $16^{\circ}$ punch angle is used. The punch clearance was observed not to have as significant an effect as the punch angle did on shearing force.

Although the reduction of shearing forces using angled punches is a practical and costeffective method, it leads to deformations on the punched part. The parts punched out by using the angled punch were sliced parallelly and orthogonally to the planes of the punch slope and the resulting amount of deformation was investigated. As the punch angle increased, the amount of deformation went up. However, no deformation was observed on the strip. This leads to the conclusion that angled punches may better be suited for piercing dies.

The results obtained from the experiments and the output from a fuzzy logic model were compared and found to be highly similar. Using the fuzzy logic model, the shearing force values were calculated (extrapolated) for the intermediate values between the data points in the angle range of $0^{\circ}$ to $16^{\circ}$ and clearances of $0.5 \%$ t to $0.9 \%$ t, which were not covered in the experiments.

When a punch angle is used, the required penetration depth is increased for the punchout operation to be fully completed. Consequently, this increase in the required penetration depth may lead to accelerated wear on the punch tool.

In the later stages of the study, the effect of bi-directional punches and matrices on the shear force can be analyzed. An experimental study can be conducted to determine the effect on the shear force of angled punches in sheet parts with different materials and thickness. In addition, the influence of the punch angle on corrosion can be investigated.

\section{REFERENCES}

[1] Kleiner, M.; Geiger, M.; Klaus, A. Manufacturing of Lightweight Components by Metal Forming, CIRP Annals - Manufacturing Technology 2003, 52 (2), 521-542. DOI:10.1016/S0007-8506(07)60202-9

[2] Wang, X.Z.; Masood, S.H. Investigation of die radius arc profile on wear behaviour in sheet metal processing of advanced high strength steels, Materials and Design 2011, 32, 1118-1128. DOI:10.1016/j.matdes.2010.11.005

[3] Karjalainen, J. A.; Mäntyjärvi, K.; Juuso, M. Punching Force Reduction with Wave-Formed Tools, Key Engineering Materials 2007, 344, 209-216. DOI: 10.4028/www.scientific.net/KEM.344.209 
Experimental Examination of Effects of Punch Angle and Clearance on Shearing Force and Estimation of Shearing Force Using Fuzzy Logic

[4] Mackensen, A.; Golle, M.; Golle, R.; Hoffmann, H. Experimental investigation of the cutting force reduction during the blanking operation of AHSS sheet materials, CIRP Annals - Manufacturing Technology 2010, 59 (1), 283-286. DOI:10.1016/j.cirp.2010.03.110

[5] Kutuniva, K.; Karjalainen, J. A.; Mäntyjärvi, K. Effect of Convex Sheared Punch Geometry on Cutting Force of Ultra-High-Strength Steel, Key Engineering Materials 2012, 504-506, 1359-1364. DOI:10.4028/www.scientific.net/KEM.504-506.1359

[6] Tekiner, Z.; Nalbant, M.; Gürün, H. An experimental study for the effect of different clearances on burr, smooth-sheared and blanking force on aluminium sheet metal, Materials and Design 2006, 27 (10), 1134-1138. DOI:10.1016/j.matdes.2005.03.013

[7] Choi, H.S.; Kim, B.M.; Ko, D.C. Effect of clearance and inclined angle on sheared edge and tool failure in trimming of DP980 sheet, Journal of Mechanical Science and Technology 2014, 28 (6), 2319-2328. DOI: $10.1007 / \mathrm{s} 12206-014-0522-7$

[8] Lo, S.P.; Chang, D.Y.; Lin, Y.Y. Relationship between the Punch-Die Clearance and Shearing Quality of Progressive Shearing Die, Materials and Manufacturing Processes 2010, 25 (8), 786-792. DOI: 10.1080/10426910903447295

[9] Hambli, R.; Kobi, S.; Guerin, F.; Dumon, B. Relationships Between Blanking Force and Part Geometry vs. Clearance, Tool Wear, and Sheet Thickness, Quality Engineering 2002, 15 (2), 197-207, DOI: 10.1081/QEN-120015852

[10] Lin, J.Ch.; Lin, W.S.; Lee, K.S.; Tong, J.L. The optimal clearance design of micro-punching die, Journal of Achievements in Materials and Manufacturing Engineering 2008, 29 (1), 79-82.

[11] Gram, M.D.; Wagoner, R.H.; Fineblanking of high strength steels: Control of material properties for tool life, Journal of Materials Processing Technology 2011, 211 (4) 717-728. DOI:10.1016/j.jmatprotec.2010.12.005

[12] Le, Q.B.; deVries, J.A.; Golovashchenko, S.F.; Bonnen, J.J.F. Analysis of sheared edge formability of aluminum, Journal of Materials Processing Technology 2014, 214, 876-891. DOI:10.1016/j.jmatprotec.2013.11.021

[13] Quazi, T.Z.; Shaikh R.S. An Overview of Clearance Optimization in Sheet Metal Blanking Process, International Journal of Modern Engineering Research 2012, 2 (6), 4547-4558.

[14] Armunanto V. B.; Cahyantoro, Y.; Priyanto, K. A Circularity Analysis of Different Clearances in the Sheet Metal Punching Process, International Journal of Engineering and Advanced Technology 2012, 2 (2), 277-280.

[15] Ragu, K. Experimental Analysis of Die Clearance Distribution in a Presstool Assembly, Transactions of Famena 2014, 38 (4), 55-64.

[16] Jaafar, H.; Mori, K.; Abe, Y. Correction of eccentricity between punch and die in slight clearance punching of ultra-high strength steel sheets, Procedia Engineering 2014, 81, 843-848. DOI: 10.1016/j.proeng.2014.10.086

[17] Jaafar, H.; Mori, K.; Abe, Y.; Nakanishi, K. Automatic centring with moving die for cold small clearance punching of die-quenched steel sheets, Journal of Materials Processing Technology 2016, 227, 190-199. DOI:10.1016/j.jmatprotec.2015.08.010

[18] Gustafsson, E.; Oldenburg, M.; Jansson, A. Design and validation of a sheet metal shearing experimental procedure, Journal of Materials Processing Technology 2014, 214, 2468-2477. DOI:10.1016/j.jmatprotec.2014.05.013

[19] Gustafsson, E.; Oldenburg, M.; Jansson, A. Experimental study on the effects of clearance and clamping in steel sheet metal shearing, Journal of Materials Processing Technology 2016, 229, 172-180. DOI:10.1016/j.jmatprotec.2015.09.004

[20] Mori, K.; Saito, S.; Maki, S. Warm and hot punching of ultra high strength steel sheet, CIRP Annals Manufacturing Technology 2008, 57, 321-324. DOI:10.1016/j.cirp.2008.03.125

[21] Naderi, M.; Ketabchi, M.; Abbasi, M.; Bleak, W. Semi-hot Stamping as an Improved Process of Hot Stamping, Journal of Materials Science \& Technology 2011, 27 (4) 369-376. DOI:10.1016/S10050302(11)60076-5

[22] Mori, K.; Maeno, T.; Fuzisaka, S. Punching of ultra-high strength steel sheets using local resistance heating of shearing zone, Journal of Materials Processing Technology 2012, 212, 534-540.

DOI:10.1016/j.jmatprotec.2011.10.021 
[23] So, H.; Faßmann, D.; Hoffmann, H.; Golle, R.; Schaper, M. An investigation of the blanking process of the quenchable boron alloyed steel 22MnB5 before and after hot stamping process, Journal of Materials Processing Technology 2012, 212, 437-449. DOI:10.1016/j.jmatprotec.2011.10.006

[24] Husson, C.; Correia, J.P.M.; Daridon, L.; Ahzi, S. Finite elements simulations of thin copper sheets blanking: Study of blanking parameters on sheared edge quality, Journal of Materials Processing Technology 2008, 199, 74-83. DOI:10.1016/j.jmatprotec.2007.08.034

[25] Subramonian, S.; Altan, T.; Campbell, C.; Ciocirlan, B. Determination of forces in high speed blanking using FEM and experiments, Journal of Materials Processing Technology 2013, 213, 2184-2190. DOI: 10.1016/j.jmatprotec.2013.06.014

[26] Mitsomwang, P.; Nagasawa, S. Effects of shearing parameters on cutting characteristics ofpolycarbonate sheet subjected to straight punch/die shearing, Journal of Materials Processing Technology 2015, 220, 46-57. DOI: 10.1016/j.jmatprotec.2015.01.007

[27] Achouri, M.; Germain, G.; Santo, P.D.; Saidane, D. Experimental and numerical analysis of micromechanical damage in the punching process for High-Strength Low-Alloy steels, Materials and Design 2014, 56, 657-670. DOI: 10.1016/j.matdes.2013.11.016

Submitted: $\quad 28.11 .2015$

Accepted: $\quad 20.9 .2016$
Assist.Prof. Hakan Gürün

Assoc. Prof. Abdulmecit Güldaş

Department of Manufacturing Engineering Gazi University Faculty of Technology 06500 Teknikokullar Ankara Turkey

Mustafa Göktaş

Technical Sciences Vocational School, Department of Machine, Gazi University, Ankara Turkey 